\title{
Major Soils of Bella Unión Area in Northwestern Uruguay $^{1}$
}

\author{
M. A. Lugo-López, Juan P. Carnelli, G. Acevedo and L. H. Rivera ${ }^{2}$
}

ABSTRACT

The soils of the area of Bella Union are deep, of high inherent fertility, and can hold and supply sufficient amounts of water to a growing crop. They are mostly sandy clay loams and clay loams. Soil pH varies between 5.2 and 6.4. Some $38 \%$ of the soils have drainage problems mostly because of underlying impervious layers dominated by montmorillonitic clays. Irrigation and drainage are essential to guarantee high levels of crop production. Erosion can be a problem in some of the soils if they are not adequately protected. The use of open drains of suitable depth and spacing will help to maintain an optimum environment for the crops and, if well designed, can also help to minimize soil erosion.

\section{INTRODUCTION}

The area around Bella Unión, in northwestern Uruguay, offers exceptional opportunities for crop production and livestock raising under adequate management. Bella Unión is located at lat. $30^{\circ} 19^{\prime} \mathrm{S}$ and long. $57^{\circ} 34^{\prime} \mathrm{W}$ at the frontiers with Brazil and Argentina. Bella Union is 640 $\mathrm{km}$ from Montevideo and $140 \mathrm{~km}$ from both Artigas, capital city of the Department, and Salto, the nearest towns with airports. There are railroad connections between Bella Unión and Montevideo. However, the network of rural roads is poor and transportation costs of sugarcane, livestock, other produce and fertilizer are high. In the Bella Union area, there are around 10,000 inhabitants; about one-half of them in rural areas. During the sugarcane harvesting season, many workers immigrate from Brazil. Nearly $9 / 10$ of the population depend directly for their living on the operations of the sugar industry.

Considerable effort is underway to increase sugarcane production as a source of both sugar and energy. The needs of Uraguay for total fermentable solids as sources of fuel and chemical feedstocks are becoming urgent. There is also a growing need of molasses as a source of ethanol for motor fuel. Marked interest is also evident in fostering the production of horticultural crops for the large Montevideo market.

This paper reports on soil studies conducted at the Bella Unión area in an effort to evaluate the situation and provide basic data to strengthen agricultural development.

\footnotetext{
${ }^{1}$ Manuscript submitted to Editorial Board January 12, 1983.

${ }^{2}$ Professor and Soil Scientist (ret., now Consultant), Agricultural Experiment Station, University of Puerto Rico, Mayagüez Campus, Rio Piedras, P.R., Ingeniero Agrónomo, Departamento Agricola, Cooperativa Agropecuaria Ltda. Norte Uruguayo, Bella Unión, Uruguay; State Soil Scientist, and former State Soil Scientist (ret.), USDA Soil Conservation Service, Caribbean Area, San Juan, P. R.
} 


\section{PROCEDURE}

All available information from the area was studied and critically evaluated, including a reconnaissance soil survey report of an area of 18,621 ha (1) and a more detailed survey report of 4,970 ha of land in the Calagua area (3).

Soil profiles were examined and described throughout the area. Data were obtained from selected soils on bulk density, and water retained at $1 / 10,1 / 3,1$ and 15 atmospheres of tension (6). Laboratory determinations were made on $\mathrm{pH}$, organic matter, cation exchange capacity and exchangeable $\mathrm{Ca}, \mathrm{Mg}, \mathrm{K}$ and $\mathrm{Na}(2)$.

\section{CLIMATE}

The climate of Bella Union is subhumid, subtropical. Mean monthly rainfall is $105 \mathrm{~mm} .^{3}$ The driest months are from May through September. The lowest rainfall occurs in July: $73 \mathrm{~mm}$; the highest in March: 132 $\mathrm{mm}$. In some years, there are severe dry spells that can subject crops to undue moisture stress. From December 8, 1975 to October 2, 1976, there were four dry spells: $35 \mathrm{~mm}$ (Dec. 8 to Jan. 2); $2.8 \mathrm{~mm}$ (March 12 to April 3); $26 \mathrm{~mm}$, (June 4 to July 31) and $9.5 \mathrm{~mm}$ (Aug. 7 to Oct. 2). From May 26 to July 4, 1977, rainfall was only $34.2 \mathrm{~mm}$. These data show the erratic rainfall distribution and highlights the need for irrigation in order to provide sufficient moisture for crop growth. The months of more rainfall are also those of more sunlight hours. The monthly average is 224 sunlight hours. Mean minimum and mean maximum temperatures follow the same trend: May through September are the cooler months. Mean minimum temperatures range from $8^{\circ} \mathrm{C}$ in June, July and August to $18^{\circ} \mathrm{C}$ in November, December and January. Mean maximum temperatures range from $19.2^{\circ} \mathrm{C}$ in August and September to $32^{\circ} \mathrm{C}$ in December, January and February. In some years, frost can cause considerable damage to crops. Marked production dips attributable to frosts were recorded in 1966, 1967 and 1976. Again, on July 15, 1980, there was a severe frost. Mean monthly evaporation ranges from $70 \mathrm{~mm}$ in July to 280 in December. Maximum daily evaporation occurs in January. Mean monthly relative humidity ranges from $56 \%$ in December to $80 \%$ in June; wind velocity, from $203 \mathrm{~km} /$ day in January to $275 \mathrm{~km} /$ day in June. Agroclimatologically, the area is characterized by an ustic soil moisture regime and a mesic soil temperature regime.

\section{SOILS}

Descriptions of typical profiles of major soils of the Bella Unión area are presented in table 1 (see also figures 1 to 4 ). The following tabulation

\footnotetext{
${ }^{3}$ Mean of 36 recorded years.
} 
TABLE 1.-Descriptions of key pedons of the major soils of the Bella Union area

\begin{tabular}{|c|c|c|c|c|}
\hline Great group & $\begin{array}{c}\text { Soil } \\
\text { series }\end{array}$ & Horizon & Depth & Profile description \\
\hline \multicolumn{5}{|r|}{$\mathrm{cm}$} \\
\hline \multirow[t]{7}{*}{ Pelluderts } & LB2 & $\mathrm{A}^{1}$ & $0-20$ & $\begin{array}{l}\text { Black (10YR 2/1) clay loam; strong me- } \\
\text { dium and coarse granular structure; fri- } \\
\text { able to firm, sticky, plastic; gradual } \\
\text { boundary. }\end{array}$ \\
\hline & & $A^{3}-B_{1}$ & $20-40$ & $\begin{array}{l}\text { Black (10YR 2/1) clay loam to clay; } \\
\text { strong, coarse granular structure; } \\
\text { sticky, very plastic; common pebbles; } \\
\text { diffuse boundary. }\end{array}$ \\
\hline & & $\mathrm{B}_{2}$ & $40-60$ & $\begin{array}{l}\text { Very dark gray to black (10YR } 2.5 / 1 \text { ) } \\
\text { clay; medium subangular blocky struc- } \\
\text { ture parting to strong fine and medium } \\
\text { granular; sticky, very plastic; some } \\
\text { slickensides; common pebbles; gradual } \\
\text { boundary. }\end{array}$ \\
\hline & & $\mathrm{B}_{3}$ & $60-70(90)$ & $\begin{array}{l}\text { Dark gray to dark grayish brown (10YR } \\
\text { 4/1.5) with black (10YR 2/1) nodules; } \\
\text { clay; moderate medium and coarse sub- } \\
\text { angular blocky structure; sticky, very } \\
\text { plastic; common slickensides; clear ir- } \\
\text { regular boundary. }\end{array}$ \\
\hline & & $\mathrm{C}_{1 \mathrm{ca}}$ & $70(90)-110$ & $\begin{array}{l}\text { Brown to dark ( } 7.5 \text { YR } 4 / 2-4 / 4 \text { ) clay; } \\
\text { sticky, very plastic; common medium } \\
\mathrm{CaCO}_{3} \text { concretions; clear boundary. }\end{array}$ \\
\hline & & $\mathrm{C}_{2}$ & $110-120$ & $\begin{array}{l}\text { Light yellowish brown }(2.5 \mathrm{Y} 6 / 4) \text { with } \\
\text { brown }(7.5 \mathrm{YR} 4 / 4) \text { nodules; loam; ab- } \\
\text { rupt boundary. }\end{array}$ \\
\hline & & $\mathrm{R}$ & $120-129$ & Unweathered basalt. \\
\hline \multirow[t]{3}{*}{ Hapludalfs ${ }^{2}$} & $\mathrm{~S} 2$ & $A_{1}$ & $0-20$ & $\begin{array}{l}\text { Very dark grayish brown (10YR 3/2) } \\
\text { moist, grayish brown (10YR 4.5/2) dry; } \\
\text { sandy loam; weak medium subangular } \\
\text { blocky structure; very friable; gradual } \\
\text { boundary. }\end{array}$ \\
\hline & & $\mathrm{A}_{3}$ & $20-35$ & $\begin{array}{l}\text { Very dark brown (l0YR 2/2) moist dark } \\
\text { grayish brown (10YR 4/2) dry; gravelly } \\
\text { sandy clay loam to gravelly sandy loam; } \\
\text { weak to moderate fine and medium } \\
\text { subangular blocky structure; clear } \\
\text { boundary. }\end{array}$ \\
\hline & & $\mathrm{B}_{21 \mathrm{~L}}$ & $35-50$ & $\begin{array}{l}\text { Very dark gray to black ( } 10 \mathrm{YR} 2.5 / 1 \text { ) } \\
\text { with common medium prominent yel- } \\
\text { lowish red (5YR 5/8) mottles; gravelly } \\
\text { heavy sandy clay loam; strong medium } \\
\text { prismatic structure; sticky, plastic; me- } \\
\text { dium continuous clay films; common } \\
\text { fine hard iron and manganese concre- } \\
\text { tions; clear boundary. }\end{array}$ \\
\hline
\end{tabular}


Table 1-Continued

\begin{tabular}{|c|c|c|c|c|}
\hline Great group & $\begin{array}{c}\text { Soil } \\
\text { series }\end{array}$ & Horizon & Depth & Profile description \\
\hline & & $\mathrm{B}_{22 \mathrm{t}}$ & $50-65$ & $\begin{array}{l}\text { Dark gray (10YR 4/1) with many medium } \\
\text { and coarse prominent strong brown } \\
\text { (7.5YR 5/8) and yellowish brown } \\
\text { (10YR 5/6) mottles; sandy clay loam to } \\
\text { clay; strong, medium and coarse pris- } \\
\text { matic structure; sticky, plastic; continu- } \\
\text { ous clayfilms; common fine iron and } \\
\text { manganese concretions; gradual bound- } \\
\text { ary. }\end{array}$ \\
\hline & & $\mathrm{B}_{23 t}$ & $65-90$ & $\begin{array}{l}\text { Gray (5Y 5/1) with common coarse prom- } \\
\text { inent strong brown ( } 7.5 \text { YR } 5 / 8 \text { ) mot- } \\
\text { tles; gravelly sandy clay loam; coarse } \\
\text { prismatic parting to strong medium an- } \\
\text { gular blocky structure; sticky, plastic; } \\
\text { continuous clay films; common, coarse, } \\
\text { very friable iron and manganese con- } \\
\text { cretions; gradual boundary. }\end{array}$ \\
\hline & & $\mathrm{B}_{3}$ & $90-105$ & $\begin{array}{l}\text { Gray (5Y 5/1) and reddish brown (5YR 4/ } \\
\text { 4); gravelly sandy clay loam; moderate } \\
\text { medium angular and subangular blocky } \\
\text { structure; sticky, plastic; discontinuous } \\
\text { clay films; common fine iron and man- } \\
\text { ganese concretions; gradual boundary. }\end{array}$ \\
\hline & & $\mathrm{C}$ & $105-110$ & Brown (7.5YR 5/3) and grayish brown \\
\hline
\end{tabular}
(10YR 5/2) gravelly sandy clay loam.

\begin{tabular}{|c|c|c|c|c|}
\hline \multirow[t]{6}{*}{ Argiudolls $^{3}$} & $\mathrm{~F} 2$ & $\mathrm{~A}_{1}$ & $0-15$ & $\begin{array}{l}\text { Black (10YR 2/1) clay loam; strong me- } \\
\text { dium granular structure; gradual } \\
\text { boundary. }\end{array}$ \\
\hline & & $\mathrm{A}_{3}$ & $15-30$ & $\begin{array}{l}\text { Black (10YR 2/1) gravelly clay loam; } \\
\text { moderate to strong fine granular and } \\
\text { subangular blocky structure; gradual } \\
\text { boundary. }\end{array}$ \\
\hline & & $\mathrm{B}_{2 t}$ & $30-40$ & $\begin{array}{l}\text { Black (10YR 2/1) clay; strong medium } \\
\text { and fine subangular blocky structure; } \\
\text { thin discontinuous clay filras; clear } \\
\text { boundary. }\end{array}$ \\
\hline & & $\mathrm{B}_{3}$ & $40-50$ & $\begin{array}{l}\text { Dark gray ( } 7.5 \text { YR } 3 / 2) \text { and brown }(7.5 Y R \\
4 / 4) \text { with very dark gray (10YR } 3 / 1) \\
\text { and black (10YR } 2 / 1) \text { coatings; clay; } \\
\text { clear and abrupt boundary. }\end{array}$ \\
\hline & & $\mathrm{C}_{1 \mathrm{cu}}$ & $50-65$ & $\begin{array}{l}\text { Dark brown (7.5YR } 3 / 2) \text { and light brown } \\
\text { (7.5YR } 6 / 4) \text { with pinkish white }(7.5 \mathrm{YR} \\
8 / 2) \text { and strong brown ( } 7.5 \mathrm{YR} 5 / 6) \\
\text { nodules; clay; clear boundary. }\end{array}$ \\
\hline & & $\mathrm{C}_{2 c a}$ & $6 \bar{i}-70$ & Fray Bentos pink tuff. \\
\hline
\end{tabular}


Table 1-Continued

\begin{tabular}{|c|c|c|c|c|}
\hline Great group & $\begin{array}{c}\text { Soil } \\
\text { series }\end{array}$ & Horizon & Depth & Profile description \\
\hline \multirow[t]{6}{*}{ Argiudolls ${ }^{4}$} & LI & $\mathrm{A}_{1}$ & $0-25$ & $\begin{array}{l}\text { Very dark grayish brown (10YR } 3 / 2) \\
\text { sandy clay loam; weak medium suban- } \\
\text { gular blocky structure; friable; gradual } \\
\text { boundary. }\end{array}$ \\
\hline & & $\mathrm{A}_{3}$ & $25-35$ & $\begin{array}{l}\text { Very dark brown (10YR } 2 / 2) \text { sandy clay } \\
\text { loam; weak to moderate medium and } \\
\text { fine subangular blocky structure; clear } \\
\text { boundary. }\end{array}$ \\
\hline & & $\mathrm{B}_{21 \mathrm{t}}$ & $35-45$ & $\begin{array}{l}\text { Very dark gray (10YR 3/1) sandy clay } \\
\text { loam; strong coarse angular blocky } \\
\text { structure; sticky, plastic; continuous } \\
\text { clay films; gradual boundary. }\end{array}$ \\
\hline & & $\mathrm{B}_{22 \mathrm{t}}$ & $45-55$ & $\begin{array}{l}\text { Very dark gray }(10 \text { YR } 3 / 1) \text { sandy clay } \\
\text { loam; with many cobbles; sticky, plas- } \\
\text { tic; gradual boundary. }\end{array}$ \\
\hline & & $\mathrm{B}_{23 \mathrm{t}}$ & $55-65$ & $\begin{array}{l}\text { Dark gray (10YR 4/1) with few fine faint } \\
\text { yellowish brown (10YR 5/6) mottles; } \\
\text { sandy clay loam and sandy clay; strong } \\
\text { coarse angular blocky structure; sticky, } \\
\text { very plastic; clear and abrupt boundary. }\end{array}$ \\
\hline & & $\mathrm{C}_{\mathrm{cs}}$ & $65-75$ & $\begin{array}{l}\text { Brown }(7.5 Y R 5 / 4) \text { clay loam; few me- } \\
\text { dium } \mathrm{CaCO}_{3} \text { concretions. }\end{array}$ \\
\hline
\end{tabular}

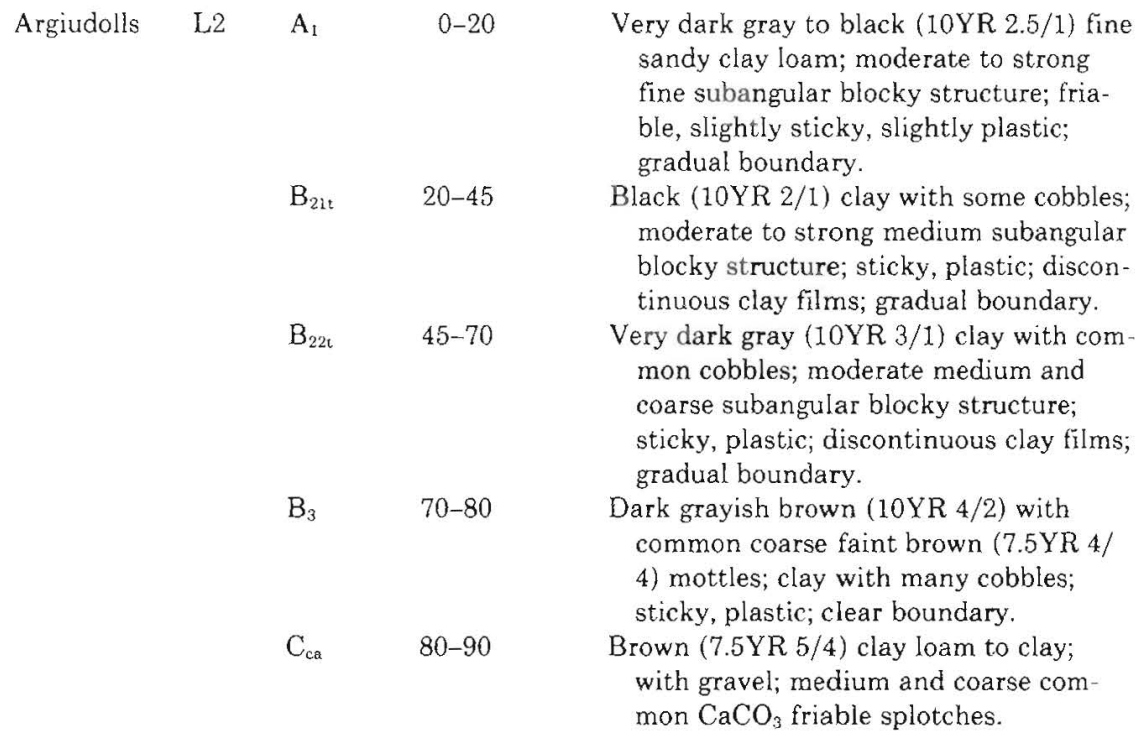


Table 1-Continued

\begin{tabular}{|c|c|c|c|c|}
\hline Great group & $\begin{array}{c}\text { Soil } \\
\text { series }\end{array}$ & Horizon & Depth & Profile description \\
\hline \multirow[t]{7}{*}{ Argiudolls } & LF2 & $A_{p}$ & $0-20$ & $\begin{array}{l}\text { Very dark brown to black (10YR } 2 / 1.5 \text { ); } \\
\text { clay loam with some cobbles; moderate } \\
\text { to strong medium and fine subangular } \\
\text { blocky structure; friable, slightly sticky, } \\
\text { plastic; gradual boundary. }\end{array}$ \\
\hline & & $\mathrm{A}_{3}$ & $20-37$ & $\begin{array}{l}\text { Black (10YR 2/1) clay loam; strong } \\
\text { coarse granular and strong fine suban- } \\
\text { gular blocky structures; friable to firm, } \\
\text { slightly sticky, plastic; gradual bound- } \\
\text { ary. }\end{array}$ \\
\hline & & $\mathrm{B}_{21 \mathrm{t}}$ & $37-50$ & $\begin{array}{l}\text { Black (10YR 2/1) clay; strong medium } \\
\text { subangular blocky structure; firm, } \\
\text { sticky, plastic; thin discontinuous clay } \\
\text { films; gradual boundary. }\end{array}$ \\
\hline & & $\mathrm{B}_{22 \mathrm{t}}$ & $50-60$ & $\begin{array}{l}\text { Black to very dark gray (10YR 2.5/I) clay } \\
\text { with common cobbles; strong medium } \\
\text { subangular blocky structure; sticky, } \\
\text { plastic; thin discontinuous clay films; } \\
\text { gradual boundary. }\end{array}$ \\
\hline & & $\mathrm{B}_{3}$ & $60-70$ & $\begin{array}{l}\text { Very dark grayish brown (10YR } 3 / 2 \text { ) clay } \\
\text { with common cobbles; moderate me- } \\
\text { dium subangular blocky structure; } \\
\text { sticky, very plastic; clear boundary. }\end{array}$ \\
\hline & & $\mathrm{C}_{\mathrm{ca}}$ & $70-80$ & $\begin{array}{l}\text { Brown (7.5YR 5/4) and strong brown } \\
(7.5 \text { YR } 5 / 6) \text { with common medium } \\
\text { faint very dark gray }(10 \mathrm{YR} 3 / 1) \text { mot- } \\
\text { tles; light clay; few medium } \mathrm{CaCO}_{3} \text { con- } \\
\text { cretions; abrupt irregular boundary. }\end{array}$ \\
\hline & L4 & $\mathrm{R}$ & $80-90$ & Fray Bentos tuff. \\
\hline
\end{tabular}

Argiudolls $\quad \mathrm{A}_{1} \quad 0-22$

Very dark grayish brown (10YR 3/2) with few fine faint dark yellowship brown (10YR 3/4) mottles; loam to silt loam; weak fine and medium subangular blocky structure; friable; gradual boundary.

$\mathrm{A}_{2}{ }^{5} \quad 22-32 \quad$ Very dark gray (10YR 3/1) with common fine faint dark yellowship brown (10YR 3/4) mottles; weak medium subangular blocky structure; friable; abrupt boundary.

$\mathrm{B}_{21 \mathrm{t}} \quad 32-40 \quad$ Very dark gray to black (10YR 2.5/1) clay; strong coarse prismatic structure; very hard, sticky, plastic; continuous clay films; gradual boundary.

$\mathrm{B}_{22 \mathrm{t}} \quad 40-76 \quad$ Very dark gray (10YR 3/1) clay; strong coarse prismatic structure; very firm, sticky, plastic; continuous clay films; gradual boundary. 
Table 1-Continued

\begin{tabular}{|c|c|c|c|c|}
\hline Great group & $\begin{array}{c}\text { Soil } \\
\text { series }\end{array}$ & Horizon & Depth & Profile description \\
\hline & & $\mathrm{B}_{3}$ & $76-94$ & $\begin{array}{l}\text { Dark gray (10YR 4/1) with few coarse } \\
\text { faint grayish brown (10YR } 5 / 2 \text { ) mot- } \\
\text { tles; clay loam to clay; moderate coarse } \\
\text { subangular blocky structure; sticky, } \\
\text { plastic; common medium iron and man- } \\
\text { ganese concretions; gradual boundary. }\end{array}$ \\
\hline & & $\mathrm{C}_{\mathrm{ca}}$ & $94-100$ & $\begin{array}{l}\text { Grayish brown }(10 \mathrm{YR} 5 / 2) \text { and light } \\
\text { brownish gray }(2.5 \mathrm{Y} 6 / 2) \text {; clay; common } \\
\text { medium and coarse } \mathrm{CaCO}_{3} \text { concretions. }\end{array}$ \\
\hline
\end{tabular}

Argiudolls $\quad$ I.4L $\quad A_{11} \quad 0-15$

$\mathrm{A}_{12}$

$15-28$

$\mathrm{A}_{2}$

$28-40$

$B_{211} \quad 40-65$

$\mathrm{B}_{22 \mathrm{t}} \quad 65-80$

$\mathrm{B}_{3 \mathrm{ex}} \quad 80-90$

$\mathrm{C}_{\mathrm{ca}} \quad 90-100$
Very dark grayish brown (10YR 3/2) loam to silt loam; weak medium subangular blocky structure; friable; gradual boundary.

Very dark gray to very dark grayish brown (10YR 3/1.5); loam to silt loam; weak medium and fine angular and subangular blocky structure; friable; clear boundary.

Dark gray to very dark gray (10YR 3.5/1) loam; very weak medium subangular blocky structure to massive; friable; few common iron and manganese concretions; clear boundary.

Very dark gray to black (10YR 2.5/1) heavy clay loam; strong coarse prismatic parting to strong coarse subangular blocky structure; sticky and plastic; continuous clay films; common fine iron and manganese concretions; gradual boundary.

Very dark gray (10YR 3/1) clay; strong coarse subangular blocky structure; sticky and plastic; continuous clay films; gradual boundary.

Very dark grayish brown (10YR 3/2) clay; moderate coarse subangular blocky structure; sticky and plastic; discontinuous clay films; few medium $\mathrm{CaCO}_{3}$ concretions; gradual boundary.

Grayish brown (10YR 5/2) clay to silty clay; sticky and plastic; common medium $\mathrm{CaCO}_{3}$ concretions.

Hapludalfs $^{6} \quad$ L42 $\quad A_{1} \quad 0-22$
Dark grayish brown (10YR 4/2) moist and light brownish gray (10YR 6/2) dry; loam; massive; friable; gradual boundary. 
Table 1-Continued

\begin{tabular}{|c|c|c|c|c|}
\hline Great group & $\begin{array}{c}\text { Soil } \\
\text { series }\end{array}$ & Horizon & Depth & Profile description \\
\hline & & $\mathrm{A}_{2}$ & $22-25$ & $\begin{array}{l}\text { Dark gray to dark grayish brown (10YR } \\
\text { 4/1.5) moist and light gray (10YR } 7 / \\
\text { 1.5) dry; loam; weak medium platy } \\
\text { structure to massive; friable; abrupt ir- } \\
\text { regular boundary. }\end{array}$ \\
\hline & & $\mathrm{B}_{21 \mathrm{t}}$ & $25-40$ & $\begin{array}{l}\text { Very dark gray (10YR 3/1) clay; moderate } \\
\text { coarse prismatic structure; sticky, very } \\
\text { plastic; discontinuous clay films; coat- } \\
\text { ings of silt and sand, gradual boundary. }\end{array}$ \\
\hline & & $\mathrm{B}_{22 \mathrm{t}}$ & $40-60$ & $\begin{array}{l}\text { Dark gray (10YR 4/1) clay; moderate } \\
\text { coarse prismatic structure; sticky, very } \\
\text { plastic; continuous clay films; gradual } \\
\text { boundary. }\end{array}$ \\
\hline & & $\mathrm{B}_{3 c s}$ & $60-90$ & $\begin{array}{l}\text { Very dark grayish brown to dark grayish } \\
\text { brown (10YR } 3.5 / 2) \text { with common } \\
\text { coarse faint dark brown ( } 7.5 \mathrm{YR} 3 / 2) \\
\text { mottles; clay loam to clay; weak to } \\
\text { moderate coarse subangular blocky } \\
\text { structure; sticky, very plastic; few me- } \\
\text { dium and coarse } \mathrm{CaCO}_{3} \text { concretions; } \\
\text { gradual boundary. }\end{array}$ \\
\hline & & $\mathrm{C}_{c a}$ & $90-100$ & $\begin{array}{l}\text { Grayish brown (10YR } 5 / 2) \text { clay loam and } \\
\text { clay; common medium and coarse } \\
\mathrm{CaCO}_{3} \text { concretions. }\end{array}$ \\
\hline
\end{tabular}

\footnotetext{
${ }^{1}$ Depth of the solum varies from 70 to 110 centimeters within short distances and in places goes directly to the unweathered basalt. Within the soil mass and at variable depths there are concentrations of pebbles in pockets.

${ }^{2}$ Depth of the $\mathrm{A}$ horizon frequently gets to $50 \mathrm{~cm}$. There are discontinuous strata of cobbles in the $\mathrm{B}_{23}, \mathrm{~B}_{3}$ and $\mathrm{C}$ horizons.

${ }^{3}$ There are cobbles throughout all the soil mass. Depth of the solum varies from 40 to $60 \mathrm{~cm}$.

${ }^{4}$ Depth of solum varies from 60 to $80 \mathrm{~cm}$, and sometimes there is a discontinuous stratum of cobbles in the base of the profile.

${ }^{5}$ The $\mathrm{A}_{2}$ horizon is discontinuous. The thickness of the $\mathrm{A}$ horizon varies between 25 to $35 \mathrm{~cm}$.

${ }^{6}$ In places the $\mathrm{C}_{\mathrm{ca}}$ horizon is inexistent and the $\mathrm{B}_{22}$ or $\mathrm{B}_{3}$ horizon lies directly on the unweathered rock (basalt).
}

shows that nearly $60 \%$ of the soils are Mollisols, which are deep soils that have a thick dark surface horizon, are relatively rich in organic matter, have a high base saturation throughout, and no deep, wide cracks in most years. Inceptisols occupy over $25 \%$ of the area. They lack horizons of clay accumulation and include the wet soils where gleying is dominant and others where the impact of the soil forming process is yet too weak. Almost $7 \%$ of the soils have been classified as Vertisols. They are dark 


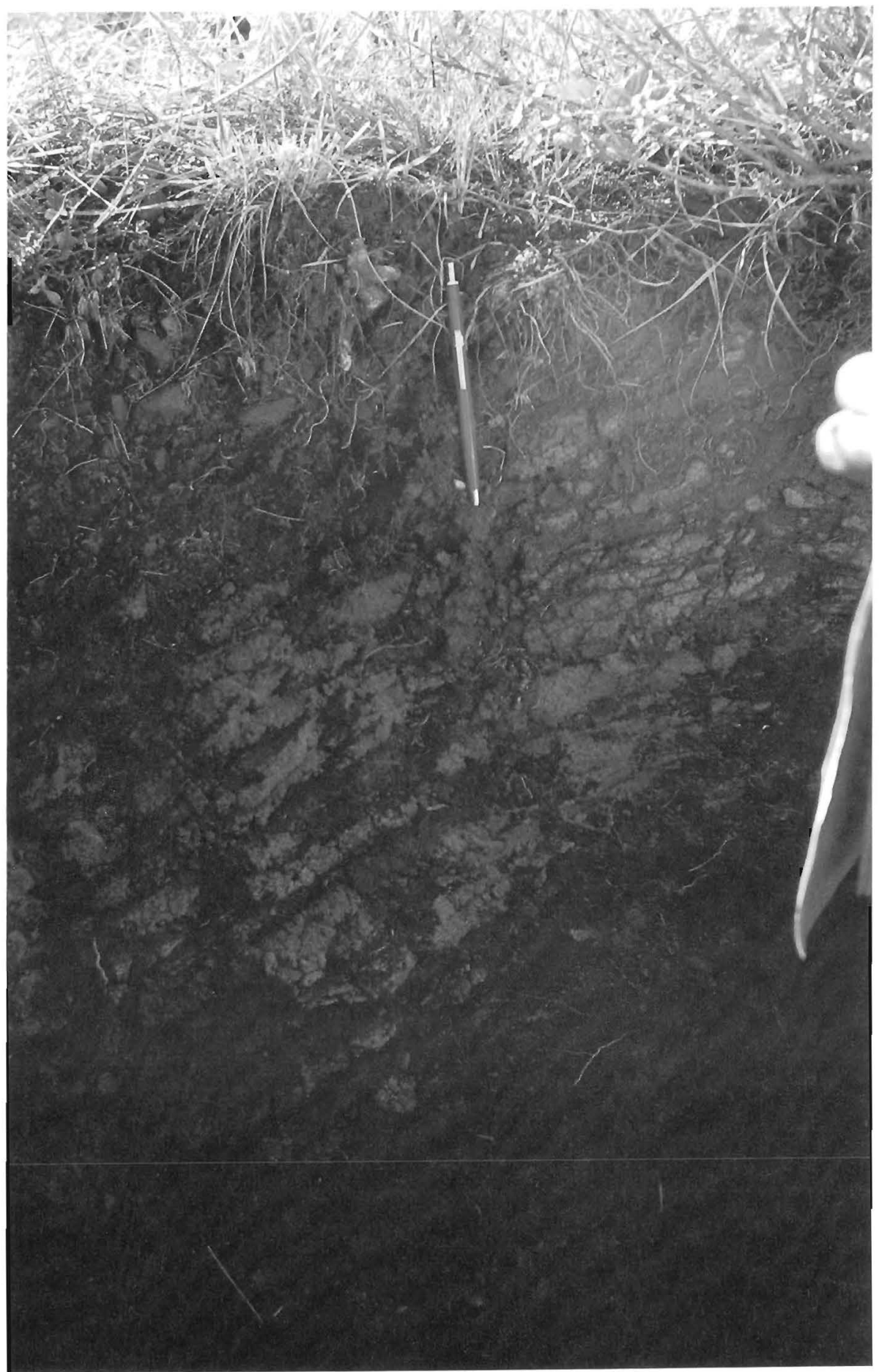

FIG. 1.-Inceptisol over basalt. 


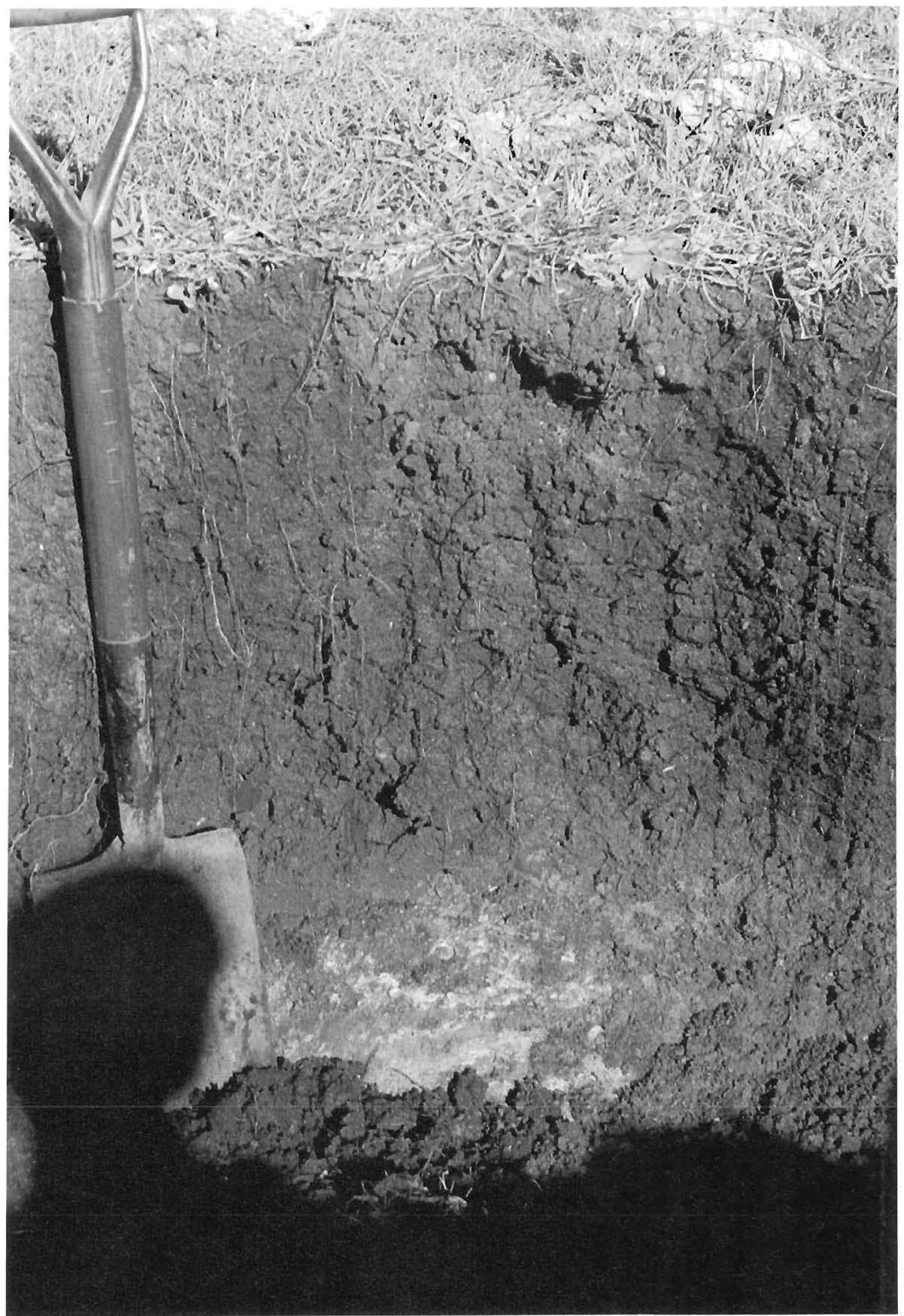

FIG. 2.-Weakly developed soil with some horizonation. Mollic epipedon in A; Argillic in $B_{t}$. 


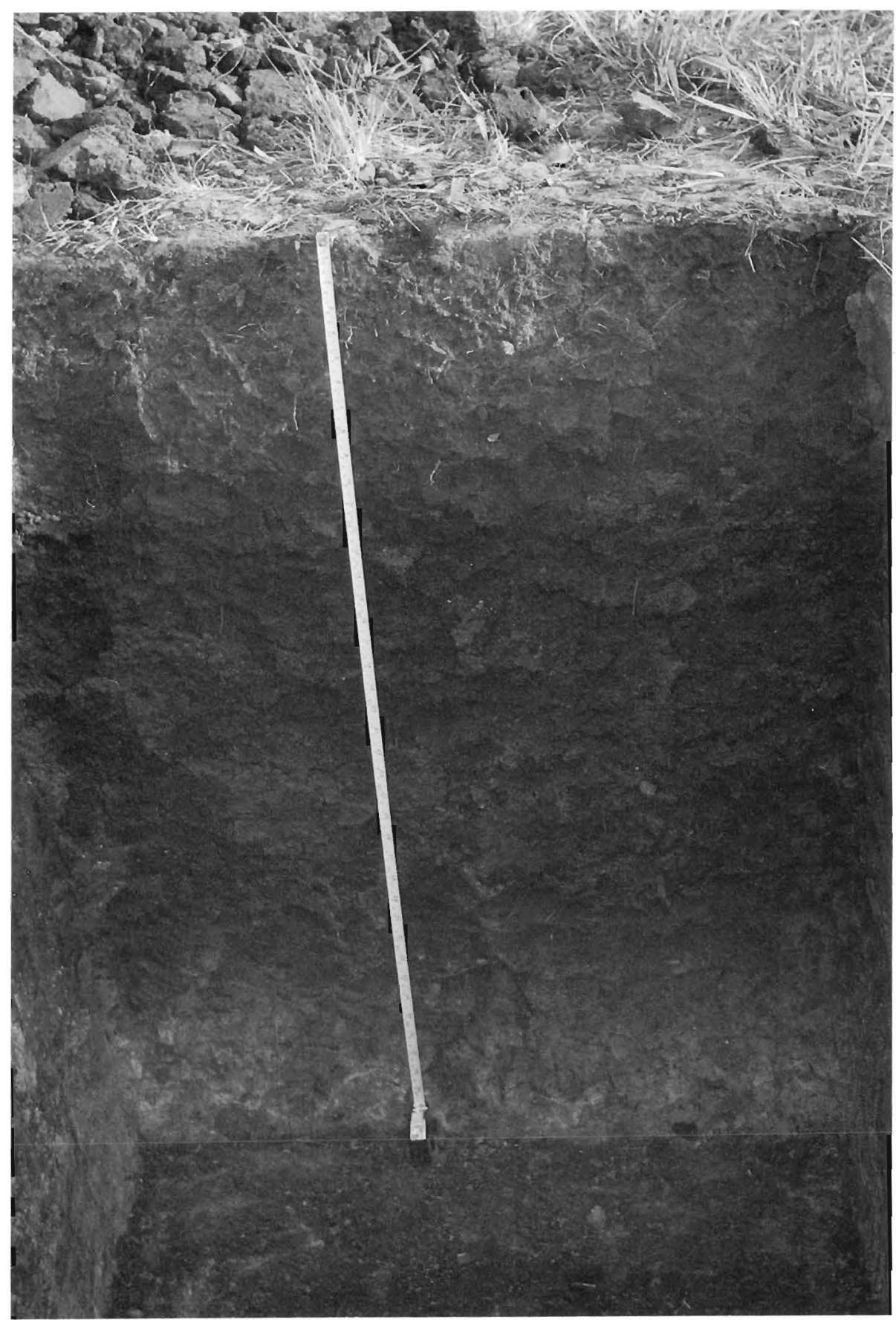

FiG. 3.-Mollisol showing clear textural differentiation between $A$ and $B_{t}$. The A-horizon is a sandy clay loam while the $B_{t}$ is clay with very slow hydraulic conductivity. 


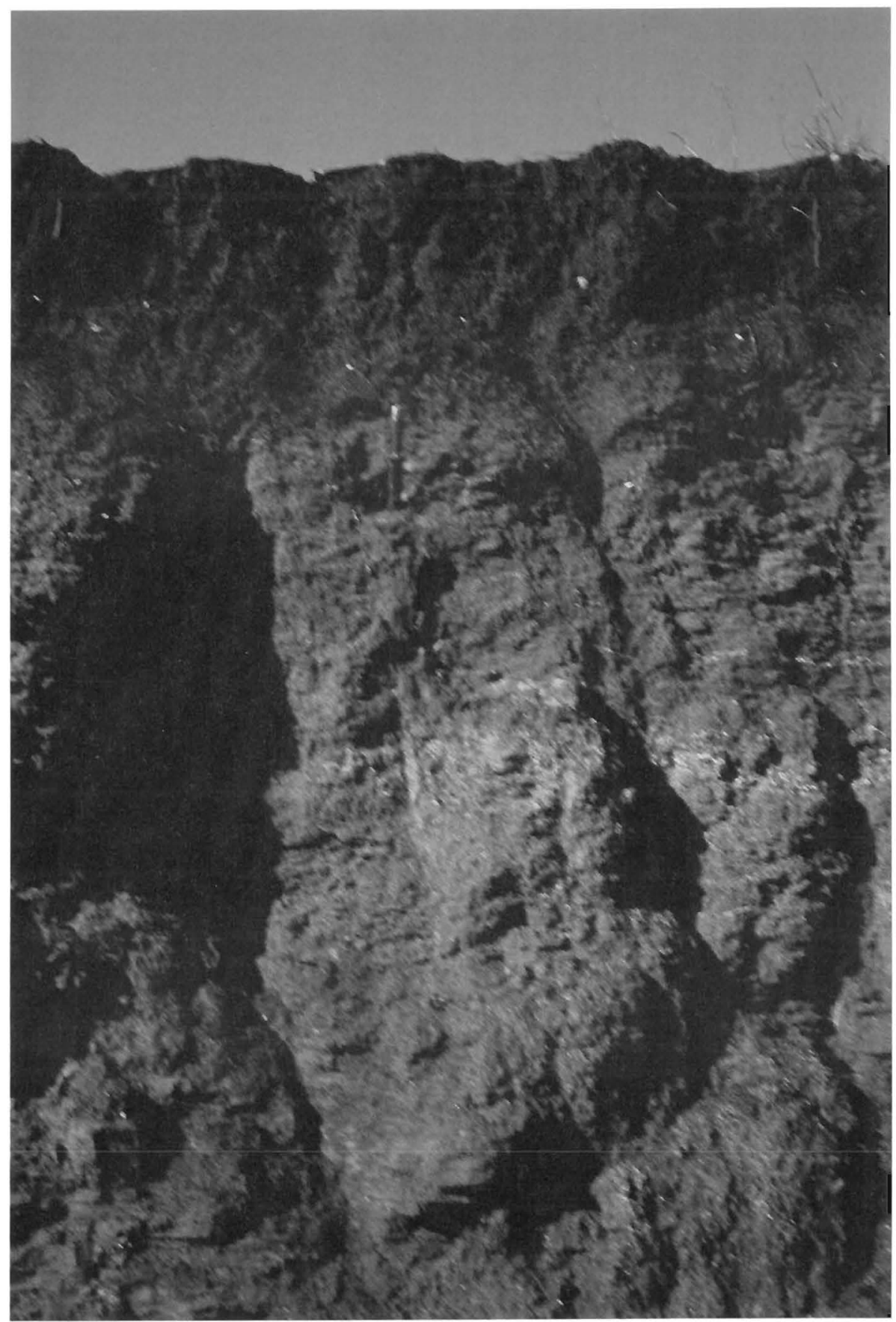

FIG. 4.-Typical Vertisol formed over silty clay alluvium with sand and gravel underlain by weathered basalt. 
clayey soils that exhibit cracks at some time in most years. Slightly over $1 \%$ of the soils are Alfisols which are relatively low in organic matter, have a relatively high base saturation and an illuvial clay horizon. The rest of the area (6 to 7\%) includes complexes of various soils that could not be mapped. They are mostly Mollisols-Inceptisols, Mollisols-Alfisols, Vertisols-Inceptisols and Vertisols-Mollisols associations.

Soil

Major properties

Mollisols

Inceptisols

Deep

Shallow

Vertisols

Alfisols very high fertility
Clayey, poorly drained, high fertility

Medium to heavy texture, well-drained, high fertility

Deep, dark, medium texture, well-developed $\mathrm{B}$ horizon, moderately well-drained, high fertility
Total area, ha 11,175

Very deep, dark, clayey, restricted drainage,

Deep, light texture, imperfect drainage, medium fertility

2,500

2,156

1,300

1,113

A soil survey of 18,621 ha reveals that more than $90 \%$ of the soils are deep and moderately deep. They are mostly sandy clay loams (over 60\%) and clay loams, derived from alluvium and basalt. There is a large variability in soils over relatively small areas. In general, the inherent fertility is rather high, but the soils need fertilizers, particularly nitrogen and potassium, for successful crop production on a continuous basis. Many of the soils have been subjected to leaching over the years by intense rainfall and poorly managed irrigation. Soil survey data indicate that in $14.6 \%$ of the soils erosion is likely to occur. This can be aggravated by inadequate management. In $38 \%$ of the soils there are drainage problems, mostly attributable to impervious underlying clay layers at 30 $\mathrm{cm}$ which extend to $1 \mathrm{~m}$ depths, dominated by montmorillonite. Unfortunately, there are no data available on infiltration and hydraulic conductivity of subsoils.

Table 2 shows land uses, capabilities and limitations of the soils. The total net area available for cropping amounts to 14,673 ha, i.e., nearly $80 \%$ of the total land area mapped. There are no apparent limitations to continuous cropping in $1 / 3$ of the net area. In slightly over $1 / 4$ of the land there is risk of compaction and crusting, whereas in slightly more than $1 / 10$ of the land there is a very high erosion risk mainly attributable to poor management on $6-12 \%$ slopes. Drainage problems are limiting factors in 1/4 of the net area. Approximately 3,735 ha out of 7,029 in class $\mathrm{V}$ are subject to flooding at least once in 7 years. 


\section{JOURNAL OF AGRICULTURE OF UNIVERSITY OF PUERTO RICO}

The following tabulation gives information on slopes.

$\begin{array}{lcc}\text { Slope } & \text { Total area, ha } & \begin{array}{c}\text { Percent of } \\ \text { total area }\end{array} \\ 0-1 & 8,996 & 48.3 \\ 1-6 & 7,584 & 40.7 \\ 6-12 & 2,041 & 11.0\end{array}$

Nearly one-half of the land falls in the $0-1 \%$ slope range, i.e., they are nearly flat and comprise the soils with restricted drainage. The other one-half of the land is in the $1-12 \%$ slope range and presents varying risks of erosion. On $11 \%$ of the land, soil erosion is a serious problem

TABLE 2.-Land use capability classes in the Bella Union area

\begin{tabular}{cccccc}
\hline $\begin{array}{c}\text { Capability } \\
\text { class }\end{array}$ & Use capability and limitations & $\begin{array}{c}\text { Total area, } \\
\text { ha }\end{array}$ & $\begin{array}{c}\text { Net area, } \\
\text { ha }^{1}\end{array}$ & $\begin{array}{c}\text { Percent of } \\
\text { net area }\end{array}$ & $\begin{array}{c}\text { Percent of } \\
\text { total area }\end{array}$ \\
\hline I & $\begin{array}{c}\text { Continuous cropping; no ap- } \\
\text { parent limitations }\end{array}$ & 4722 & 4593 & 31.3 & 25.4 \\
II $\quad \begin{array}{c}\text { Continuous cropping; risk of } \\
\text { compaction and crusting }\end{array}$ & 4278 & 4123 & 28.1 & 22.9 \\
III $\quad \begin{array}{c}\text { Continuous cropping, rela- } \\
\text { tively low fertility }\end{array}$ & 551 & 532 & 3.6 & 2.9 \\
IV $\quad$ Continuous cropping, slope, \\
$\quad \begin{array}{c}\text { high erosion risk } \\
\text { Continuous cropping, imper- } \\
\text { fect to poor drainage; some } \\
\text { soils subject to flooding }\end{array}$ & $7029^{2}$ & 3735 & 25.5 & 37.7 \\
V & & 1689 & 11.5 & 10.9 \\
\hline
\end{tabular}

' Excluding urban ureas, roads and lands subject to flooding.

${ }^{2}$ Of the 7,029 ha $44 \%(3,127)$ were exluded because they are subjected to flooding. Of these, 500 ha are probably in sugar cane.

mainly due to slope. In nearly $41 \%$ of the soils, erosion damage can be serious if the soils are not well managed. The most important factors are field layout, and irrigation and drainage designs.

Very limited data have been obtained on retention at $1 / 3$ bar, water storage at various tensions and water availability at the Calagua, CainsaCalpica and Franquia sites (tables 3 and 4). Assuming that the water held at tensions approaching $1 / 10$ atmosphere can be used by plants before it drains away, and considering the 15-atmosphere percentage as the upper limit, the available water that the soils at Calagua can supply to growing plants ranges from $8.6 \%$ in a Mollisol to $19.7 \%$ in the $\mathrm{A}$ horizon of an Alfisol. This is acceptable in view of the fact that the supply is gradually replenished with rainfall and irrigation water. The available water sharply drops to $12 \%$ in the B horizon of this soil. In all 
TABLE 3.-Bulk density, porosity and water retained at various tensions of selected soils at Calagua

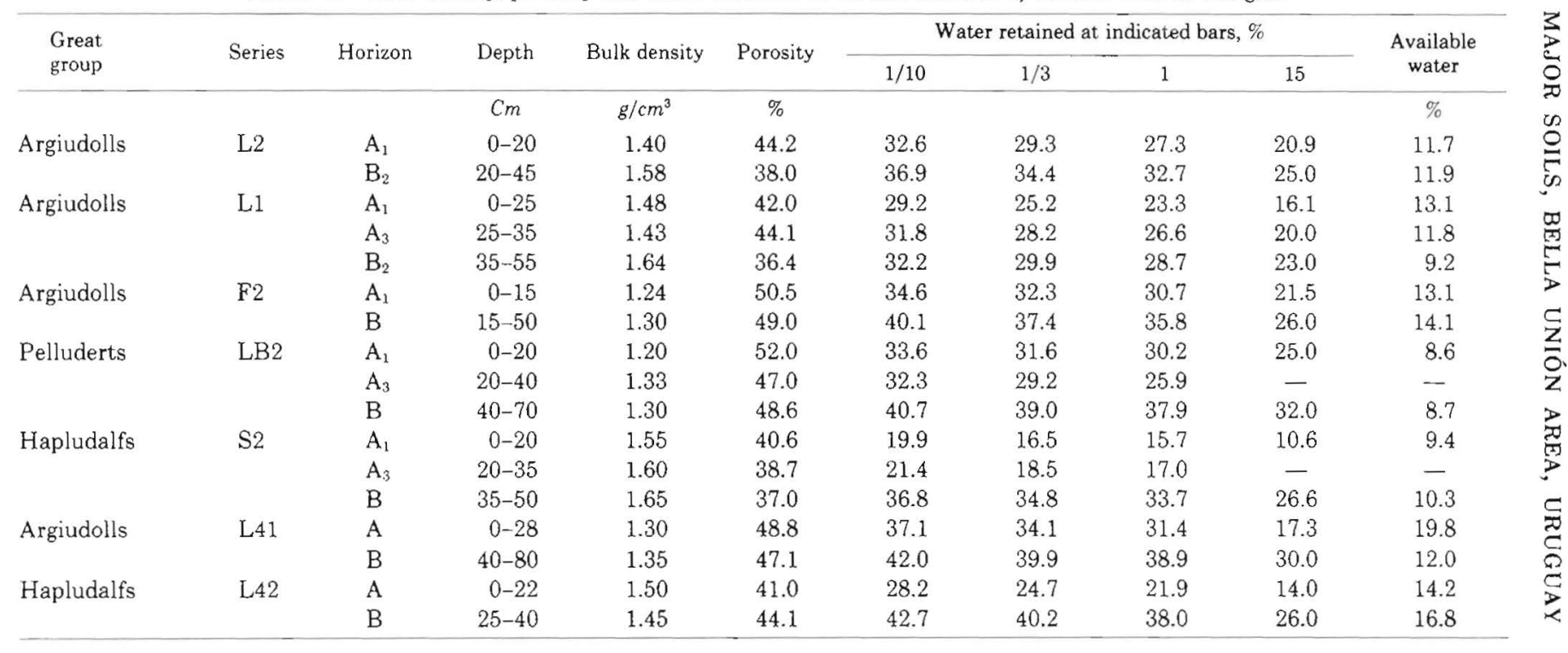




\section{JOURNAL OF AGRICULTURE OF UNIVERSITY OF PUERTO RICO}

Mollisols, the lower $\mathrm{A}_{2}$ and $\mathrm{B}$ horizons can store as much available water as the topsoil. In general, the available water supplying capacity of the soils is rather good. This is further confirmed by the data on available water on the root zone of selected soils from Calagua as shown in table 5 . Effective root zone ranges from 5 to $60 \mathrm{~cm}$. These values were estimated based on soil morphology, bulk density and proportion of macro to micropores. Available water ranges from 6 to $60 \mathrm{~mm}$. The following

TABLE 4.-Bulk density and water retention at $1 / 3$ and 15 bars at Cainsa-Calpica and Franquía Alta

\begin{tabular}{|c|c|c|c|c|c|}
\hline \multirow{2}{*}{ Location } & \multirow{2}{*}{ Depth, cm } & \multirow{2}{*}{$\begin{array}{l}\text { Bulk density } \\
\mathrm{g} / \mathrm{cm}^{3}\end{array}$} & \multicolumn{2}{|c|}{$\begin{array}{c}\text { Water retained at indicated } \\
\text { bars, } \%\end{array}$} & \multirow{2}{*}{$\begin{array}{l}\text { Available } \\
\text { water, \% }\end{array}$} \\
\hline & & & $1 / 3$ & 15 & \\
\hline \multirow[t]{4}{*}{ Cainsa-Calpica } & $0-20$ & 1.19 & 37.4 & 22.9 & 14.8 \\
\hline & $20-40$ & 1.33 & 42.0 & 29.6 & 12.4 \\
\hline & $40-60$ & 1.35 & 42.2 & 29.3 & 18.9 \\
\hline & $60-80$ & 1.48 & 41.6 & 25.2 & 16.4 \\
\hline Franquia & $0-20$ & 1.45 & 21.1 & 8.3 & 12.8 \\
\hline \multirow[t]{4}{*}{ Alta } & $20-40$ & 1.67 & 24.4 & 10.8 & 13.6 \\
\hline & $40-60$ & 1.57 & 35.7 & 20.6 & 15.1 \\
\hline & $60-80$ & 1.64 & 32.8 & 20.4 & 12.4 \\
\hline & $80-100$ & 1.67 & 32.2 & 18.7 & 13.5 \\
\hline
\end{tabular}

TABLE i.-Effective root zone and available water of the soils at Calagua

\begin{tabular}{|c|c|c|c|c|}
\hline \multirow{2}{*}{ Soil series } & \multicolumn{2}{|c|}{ Area } & \multirow{2}{*}{$\begin{array}{l}\text { Effective root zone, } \\
\mathrm{cm}\end{array}$} & \multirow{2}{*}{$\begin{array}{l}\text { Available water, } \\
\mathrm{mm}\end{array}$} \\
\hline & Total, ha & $\%$ & & \\
\hline $\mathrm{LI}$ & 408.3 & 8.20 & 35 & 45 \\
\hline L2 & 278.5 & 5.59 & 30 & 31 \\
\hline L3 & 36.5 & 0.73 & 20 & 28 \\
\hline L4 & 182.1 & 3.65 & 25 & 50 \\
\hline $\mathrm{L} 5$ & 220.3 & 4.42 & 40 & 54 \\
\hline L41 & 91.1 & 1.83 & 30 & 60 \\
\hline $\mathrm{L} 42$ & 72.3 & 1.45 & 25 & 37 \\
\hline Li5 & 60.9 & 1.22 & 40 & 41 \\
\hline LB2 & $1,130.3$ & 22.7 & 60 & 52 \\
\hline LB3 & 99.2 & 1.99 & 30 & 33 \\
\hline LF2 & 258.1 & 5.18 & 40 & 45 \\
\hline $\mathrm{L} 51$ & 125.2 & 2.51 & 30 & 30 \\
\hline $\mathrm{F} 2$ & 206.6 & 4.15 & 50 & 67 \\
\hline $\mathrm{S} 2$ & 106.0 & 2.13 & 40 & 37 \\
\hline $\mathrm{B} 1$ & 44.5 & 0.89 & 20 & 24 \\
\hline B11 & 100.9 & 2.02 & 5 & 6 \\
\hline $\mathrm{B} 12$ & 249.5 & 5.01 & 30 & 24 \\
\hline $\mathrm{B} 13$ & 150.7 & 3.03 & 20 & 20 \\
\hline $\mathrm{B} 2$ & 286.0 & 5.74 & 45 & 40 \\
\hline SB1 & 4.5 & 0.09 & 30 & 30 \\
\hline
\end{tabular}


tabulation shows the distribution in hectares of the soils classified according to available water intervals.

Range of available
water, $\mathrm{mm}$

Less than 12

$13-24$

$25-36$

$37-48$

$49+$
Distribution

$\begin{array}{cc}H a & \%^{4} \\ 100.9 & 2.02 \\ 941.8 & 18.90 \\ 992.1 & 19.90 \\ 929.9 & 18.70 \\ 1269.9 & 25.51\end{array}$

Twenty-five percent of the soils have good available water supplying power; $57 \%$, satisfactory; and only $2 \%$, very low. In general, most of the soils at Calagua can retain sufficient moisture readily available to plants.

Bulk density values at the topsoil at Cainsa-Calpica are much more favorable than equivalent values at Calagua (table 4) and at Franquia Alta. The higher bulk density values at Calagua can be probably attributed to compaction. The most extensive soils have more macropores, a condition conducive to good internal drainage and no impedance to root penetration. This probably indicates a more favorable soil structure and better water movement throughout the profile. However, water retention and supply values are similar in the Cainsa-Calpica and Franquía Alta as in the Calagua soils.

Chemical data on selected soils of Calagua are given in table 6. Organic matter levels range from 1.69 to $5.31 \%$ in the A1 horizon and decrease gradually with depth. Cation exchange capacity (CEC) values are high and increase from the $\mathrm{A}$ to the $\mathrm{B}$ horizons. Total bases are approximately 60 to $75 \%$ or more of the CEC. Exchangeable calcium $(\mathrm{Ca})$ is usually from 50 to $75 \%$ of the total bases. These data are reliable indices of the high fertility of the soils. In general, the soils at the Bella Unión area are somewhat acid ( $\mathrm{pH} 5.2$ to 6.4) in the A horizon.

\section{POTENTIAL}

The soils of Bella Unión appear to have a great potential for sugarcane, rice, sweet sorghum, grain sorghum, forage and horticultural crops such as tomatoes, squash, melons, cabbage and others. Any program for the improvement of crop production in the area must provide for efficient irrigation at critical periods. The main sources of irrigation water are the Uruguay and Cuareim rivers. There are some streams like the Itacumbú which supply water to nearby fields. Existing irrigation systems are obsolete. Drainage is also an essential component of the water management system. The use of open drains at suitable depths and spacings will

\footnotetext{
${ }^{4}$ Percentage of total area (approx. 4,978.7 ha).
} 
TABLE 6.-Chemical data on selected soils at Calagua

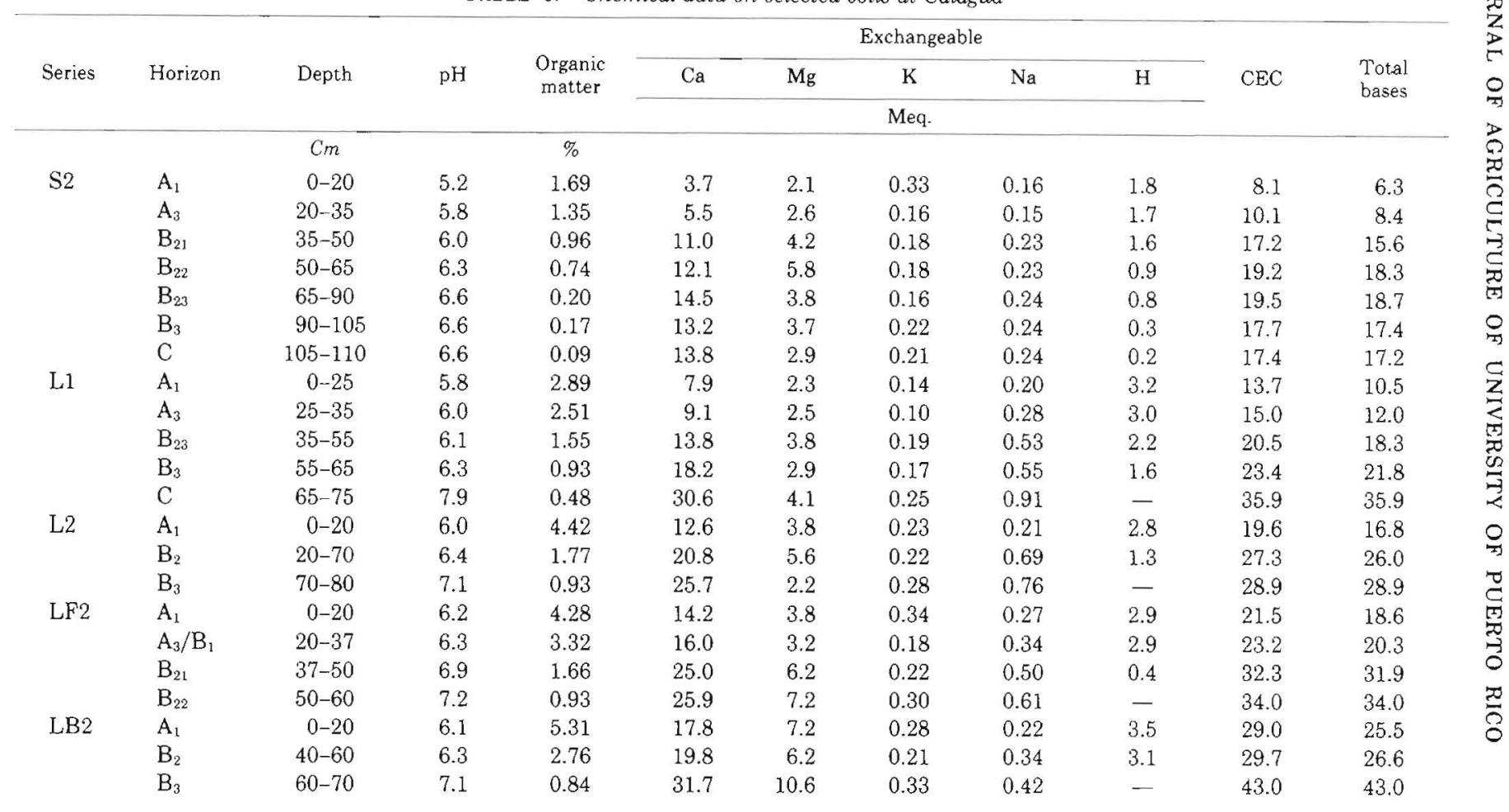




\begin{tabular}{|c|c|c|c|c|c|c|c|c|c|c|c|}
\hline \multirow[t]{5}{*}{ L42 } & $\mathbf{A}_{1}$ & $0-22$ & 6.0 & 1.35 & 4.0 & 3.1 & 0.09 & 0.47 & 1.50 & 9.2 & 7.7 \\
\hline & $\mathrm{A}_{2}$ & $22-25$ & 6.0 & 1.11 & 5.1 & 2.6 & 0.11 & 0.54 & 1.70 & 10.0 & 8.3 \\
\hline & $\mathrm{B}_{21}$ & $25-40$ & 6.2 & 1.45 & 15.4 & 3.7 & 0.17 & 1.50 & 1.90 & 22.7 & 20.8 \\
\hline & $\mathrm{B}_{22}$ & $40-60$ & 7.5 & 0.93 & 22.0 & 5.5 & 0.28 & 1.75 & - & 29.5 & 29.5 \\
\hline & $\mathrm{B}_{3}$ & $60-90$ & 8.2 & 0.35 & 26.2 & 3.1 & 0.27 & 1.60 & - & 31.2 & 31.2 \\
\hline \multirow[t]{5}{*}{ F2 } & $\mathbf{A}_{1}$ & $0-15$ & 6.4 & 3.72 & 18.1 & 2.9 & 0.43 & 0.22 & 2.3 & 24.0 & 21.7 \\
\hline & $\mathrm{B}_{1}$ & $15-30$ & 6.5 & 3.35 & 20.6 & 2.4 & 0.24 & 0.25 & 2.2 & 25.7 & 23.7 \\
\hline & $\mathrm{B}_{2}$ & $30-40$ & 6.6 & 2.45 & 22.0 & 3.8 & 0.19 & 0.31 & 0.9 & 27.2 & 26.3 \\
\hline & $\mathrm{B}_{3}$ & $40-50$ & 6.7 & 1.98 & 26.4 & 3.9 & 0.34 & 0.36 & 0.6 & 31.6 & 31.0 \\
\hline & $\mathrm{C}$ & $50-70$ & 7.6 & 0.93 & 30.3 & 4.9 & 0.35 & 0.50 & - & 36.0 & 36.0 \\
\hline \multirow[t]{4}{*}{ L41 } & $A_{1}$ & $0-28$ & 5.9 & 2.85 & 7.0 & 4.9 & 0.10 & 0.54 & 2.40 & 14.9 & 12.5 \\
\hline & $\mathrm{A}_{2}$ & $28-40$ & 6.5 & 1.25 & 6.9 & 3.1 & 0.09 & 0.51 & 1.30 & 11.9 & 13.2 \\
\hline & $\mathrm{B}_{2}$ & $40-80$ & 6.8 & 1.53 & 12.7 & 5.1 & 0.14 & 0.94 & 0.30 & 19.2 & 18.9 \\
\hline & $\mathrm{B}_{3}$ & $80-90$ & 7.9 & 0.61 & 21.2 & 5.7 & 0.24 & 1.40 & - & 28.5 & 28.5 \\
\hline
\end{tabular}


be practical. Well designed multipurpose projects involving irrigation, drainage, erosion control and production observed at the Calpica site should be followed by other groups of farmers. Land preparation should include smoothing and levelling where feasible. Farmers appear to be using more fertilizer than needed, particularly phosphorus. There is evidence of phosphorus accumulation in the soil arising from relatively large applications to previous crops. Under good management, sugarcane offers a distinct potential (4). The 8,000 ha now under sugarcane cultivation could be extended by an additional 1,500 or 2,000 ha which will help to extend the milling season and to conform to the capacity of the existing mill. Rice production with irrigation could be increased. The possibilities of sweet sorghum as an energy crop appear good, but need further investigation (5). Rainfed grain sorghum can probably be produced successfully. Short cycle horticultural crops could take advantage of the seasons and the produce could be marketed advantageously in Montevideo. Cattle and sheep will continue to be major sources of income in the area, but production could be improved through more adequate management systems.

\section{RESUMEN}

Los suelos del área de Bella Unión, en el noroeste del Uruguay, son profundos, de alta fertilidad y capaces de suministrar suficiente agua para las cosechas. Son suelos principalmente de textura franco-arcillo-arenosa y franco-arcillosa. El pH varía de 5.2 a 6.4. El 38\% de los suelos tiene problemas de desagüe, mayormente atribuibles a capas pesadas subyacentes de arcillas montmorilloníticas. Tanto el riego como el desagüe son esenciales para que las cosechas produzcan altos rendimientos. La erosión puede convertirse en un serio problema si los suelos no se protegen adecuadamente. Las zanjas, a profundidades y distancias adecuadas, pueden ayudar a proveer un ambiente óptimo en la zona de raices de las cosechas. Si estas zanjas se diseñan bien, pueden ayudar a minimizar los daños que causa la erosión.

\section{LITERATURE CITED}

1. Cooperativa Agropecuaria Ltda. Norte Uruguayo, Uruplan (Sociedad de Consultores), Relevamiento de suelos, 1976.

2. Black, C. A., Ed, 1965. Methods of soil analysis, Am. Soc. Agron., Wisconsin, Monogr. 9.

3. Kaplan, A., Zamalvide, J. and Carnelli, J. P., 1980. Estudio de suelos, Proyecto Calagua, Agrosuelos Consultores, Bella Unión, Uruguay.

4. Lugo-López, M. A., 1980. Sugarcane production at CALNU: Present situation and perspectives, Report to Multinational Agribusiness Systems, Inc.

5. Lugo-López, M. A., 1980. Sweet sorghum as an energy crop, Report to Multinational Agribusiness Systems, Inc.

6. Richards, L. A. and Weaver, L. R., 1944. Moisture retention by some irrigated soils as related to soil moisture tension, J. Agric. Res. 69: 215-35. 